\title{
Correlation between dental caries experience and the level of Streptococcus mutans and lactobacilli in saliva and carious teeth in a Yemeni adult population
}

Sabah A. Sounah ${ }^{1 *}$ and Ahmed A. Madfa ${ }^{1,2,3}$

\begin{abstract}
Objective: This study aimed to determine the relative amounts of Streptococcus mutans (SM) and lactobacilli (LBs) and their relationship with dental caries among a Yemeni adult population.

Results: A positive correlation appeared between SM and LB counts from saliva and caries tissue samples and the decayed, missing and filled teeth (DMFT) score $(p<0.05)$. There was a significant correlation between $S M$ and LBs in caries tissue $(p<0.05)$. However, there was no significant difference between $S M$ and LBs isolated from saliva samples $(p>0.05)$. The number of SM and LBs in subjects with active caries was significantly higher than that in those without active caries $(p<0.05)$. There was no significant difference between the daily habits and SM and LB or DMFT scores $(p>0.05)$, except for a significant difference between brushing frequency and DMFT score $(p<0.05)$.
\end{abstract}

Keywords: Streptococcus mutans, Lactobacilli, Quantitative, real-time PCR, Caries risk, Epidemiology, Yemeni population

\section{Introduction}

Dental caries is a major infectious disease affecting the majority of the world's population [1]. It is considered one of the most prevalent diseases, particularly in socially underdeveloped communities [2].

In the past few decades, extensive research has provided important information about the link between dental caries and salivary bacteria [3], and some studies have revealed a significant association between salivary levels of Streptococcus mutans (SM) and subsequent onset of caries [4]. Existing data on the possible association between lactobacillus (LB) saliva levels and the onset of

\footnotetext{
*Correspondence: dr_sounah@yahoo.com

${ }^{1}$ Department of Restorative and Prosthodontics, College of Dentistry,

University of Sciences and Technology, Sanaa, Yemen

Full list of author information is available at the end of the article
}

caries are less convincing [5]. Therefore, salivary LB levels might be indirectly related to caries progression [6].

Because oral bacteria are considered one of the aetiologic factors involved in caries development [7], various microbial studies have been conducted to better understand this dental problem. However, there is a lack of available data on the detection of dental caries bacterial diversity in the Yemeni adult population. In addition, culture-independent studies describing the number of distinct microorganisms in the saliva and carious lesions of Yemeni adults have not yet been published. Thus, information about the correlation between the distribution of $S M$ and LBs and caries development is needed. The current study was planned to investigate the adult population of Yemen to determine the relative amounts of $S M$ and LBs and to study their correlation with dental caries using quantitative real-time PCR.

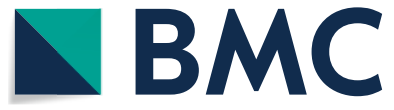

(c) The Author(s) 2020. This article is licensed under a Creative Commons Attribution 4.0 International License, which permits use, sharing, adaptation, distribution and reproduction in any medium or format, as long as you give appropriate credit to the original author(s) and the source, provide a link to the Creative Commons licence, and indicate if changes were made. The images or other third party material in this article are included in the article's Creative Commons licence, unless indicated otherwise in a credit line to the material. If material is not included in the article's Creative Commons licence and your intended use is not permitted by statutory regulation or exceeds the permitted use, you will need to obtain permission directly from the copyright holder. To view a copy of this licence, visit http://creativeco mmons.org/licenses/by/4.0/. The Creative Commons Public Domain Dedication waiver (http://creativecommons.org/publicdomain/ zero/1.0/) applies to the data made available in this article, unless otherwise stated in a credit line to the data. 


\section{Main text \\ Methods \\ Study design and population}

Ethics committee of the Faculty of Medicine and Health Sciences at UST approved this study (MECA No. 2017/01). The study sample comprised males and females with an average age of 24 years referred for treatment to the dental polyclinics of the Dental College at UST. The inclusion criteria comprised subjects with good general health, more than three carious teeth for caries-active (CA) subjects and sound teeth or one initial non-cavitation for caries-free (CF) individuals. The exclusion criteria were subjects who had any of the following conditions: systemic disorders or use of medication that might influence the dentition; mental disability; a history of antibiotic or fluoride treatment; consultation for orthodontic reasons or under orthodontic treatment. The final sample size in this study consisted of 40 individuals (20 CF and 20 CA). Written informed consent was obtained from all individual participants included in the study.

\section{Clinical examination and daily habits interview}

All examinations were performed using dental mirrors and a dental explorer. According to the WHO dental caries diagnostic criteria, clinical oral health status was assessed, and decay (D), loss due to dental caries (M) and filled (F) teeth (T) (DMFT) were observed. One examiner conducted the clinical examination using the DMFT standard. A bite-wing radiograph was obtained for each subject to confirm the depth of the lesion [8].

After the clinical examination, all subjects received interviews about their daily oral health habits. This study used a questionnaire survey adapted from earlier studies $[9,10]$. Subjects were asked about the practice of oral hygiene and the frequency of sugar consumption.

\section{Sample collection and extraction of genomic DNA}

Twenty specimens were excavated from carious teeth of CA individuals using a sterilized, sharp dental spoon excavator. The lesion in each tooth was excavated, suspended in alcohol, and kept at $-20{ }^{\circ} \mathrm{C}$ until use. One gram of the carious dentine fragment was weighed and initially dispersed manually by vortexing for $20 \mathrm{~s}$ prior to extraction of bacterial DNA $[11,12]$.

Forty saliva specimens were collected for this study, 20 specimens from CF individuals and 20 specimens from CA subjects. The saliva collection was scheduled for early morning at the beginning of the day before the patients had breakfast. Each patient was asked to swallow pre-existing saliva and then chew a standard piece of paraffin wax, and $5 \mathrm{~mL}$ of stimulated saliva was collected into a $50-\mathrm{mL}$ sterile tube, which was then taken directly to the laboratory and kept at $-20{ }^{\circ} \mathrm{C}$ until it was used $[2,8]$. Total bacterial genomic DNA was then extracted from each saliva sample using a modification based on the instructions of a published study [2, 8, 13] (Additional file 1).

\section{Bacterial strains}

The number of oral bacterial strains from two internal control species was observed in this study to construct a quantitative standard curve. $S M$ and LBs were isolated, identified, and confirmed by conventional PCR test [2]. Bacterial genomic DNA was extracted and purified according to the Qiagen bacterial extraction protocol and the company's extraction guide (Qiagen, Hilden, Germany).

\section{Quantitative real-time PCR assays}

For quantification of the total level of bacterial samples, qPCR for the targeted 16S rRNA gene was obtained on an ABI 7000 real-time PCR instrument (Applied Biosystems, California, United States) in a total reaction volume of $20 \mu \mathrm{L}$. The specific forward and reverse primers used in this study were as described and validated elsewhere $[13,14]$ (Additional file 2). The real-time PCR assay was performed in a total volume of $20 \mu \mathrm{L}$ consisting of $10 \mu \mathrm{L}$ of $2 \times$ Eva Green qPCR Mix Plus ROX (Solis Bio Dyne, Estonia), $2 \mu \mathrm{M}$ each forward and reverse primer, $5 \mu \mathrm{L}$ of template DNA and $3 \mu \mathrm{L}$ of DNA/RNAse-free water. Each sample was tested twice. Conditions of thermal cycling for all qPCR assays were set as follows: one cycle at $95^{\circ} \mathrm{C}$ for $15 \mathrm{~min}$, followed by 40 cycles of denaturation for $15 \mathrm{~s}$ at $95{ }^{\circ} \mathrm{C}$, primer annealing for $20 \mathrm{~s}$ at $60{ }^{\circ} \mathrm{C}$ for $S M$ and LBs, and elongation for $20 \mathrm{~s}$ at $72{ }^{\circ} \mathrm{C}$ for $S M$ and LBs. For the construction of quantification standard curves, the qPCR reaction mixture contained a total volume of 20 $\mu \mathrm{L}$, which consisted of $10 \times$ Eva Green qPCR Mix Plus ROX (Solis Bio Dyne, Estonia), $2 \mu \mathrm{M}$ each forward and reverse primer, $5 \mu \mathrm{L}$ of template genomic DNA from the aforementioned bacterial strains and $3 \mu \mathrm{L}$ DNA/RNAsefree water (concentration ranged from $10 \mathrm{ng} / \mu \mathrm{L}$ to $10 \mathrm{fg} /$ $\mathrm{mL}$ ) [14]. The results are expressed as the number of cells per $\mathrm{mL}$, according to the calculation method described elsewhere [13].

\section{Statistical analysis}

All data were collected and analysed statistically by Statistical Package for Social Science version 23.0 (SPSS Inc., Chicago, IL). Due to unmet assumptions of normal distribution after results of the Shapiro-Wilk test $(p<0.05)$, nonparametric tests were used. Correlations between both bacteria and the DMFT index were analysed by the nonparametric Spearman correlation coefficient. Kruskal-Wallis and Mann-Whitney U tests were used 
to determine statistically significant differences between the groups. A $p$ value less than 0.05 was considered significant.

\section{Results}

Based on qPCR results, SM and LBs were detected in $100 \%$ of the Yemeni adults (Fig. 1; Additional files 3 and 4). Table 1 displays the correlations of the relative amounts of $S M$ or LBs in both saliva and caries lesions, with DMFT scores. A positive correlation was found between $S M$ isolated from CA saliva and caries tissue samples and the DMFT score $(p<0.05)$, whereas no significant relationship was found between $S M$ isolated from caries tissue and the DMFT score $(\mathrm{p}>0.05)$. No significant relationship was found between LBs isolated from saliva and caries tissue samples with the DMFT score $(p>0.05)$. However, there was a significant inverse correlation between $S M$ and LBs isolated from caries tissue $(p<0.05)$.

When comparing both groups, the number of $S M$ and LBs in subjects with active caries was significantly higher than that in those without active caries $(p<0.05)$, as presented in Table 2. Furthermore, significant differences appeared between samples of saliva from CF subjects and both saliva and caries lesion samples from CA subjects $(p<0.05)$. However, there was no difference between the number of bacteria isolated from saliva and caries lesion samples from CA subjects $(p>0.05)$. Significantly higher DMFT scores were found in CA subjects than in CF individuals $(p<0.05)$. Decayed, missing, and filled teeth in relation to the numbers of $S M$ and LBs and the DMFT scores also showed significant differences $(p<0.05)$, as displayed in Table 2.

There were no significant differences between the daily habits (chewing khat, brushing, flossing, frequency of eating sweets, and drinking soft drinks) and $S M$ and LB
Table 1 Correlation coefficients of bacteria and caries development in caries-active individuals

\begin{tabular}{lll}
\hline & SM & LB \\
\hline Saliva samples & & \\
SM & 1.00 & 0.324 \\
LBs & 0.324 & 1.00 \\
DMFT & $0.021^{*}$ & 0.703 \\
Caries tissue samples & & \\
SM & 1.00 & 0.174 \\
LBs & $0.056^{*}$ & 1.00 \\
DMFT & 0.174 & 0.833 \\
\hline
\end{tabular}

${ }^{*} P<0.05$

levels and DMFT scores $(p>0.05)$, except for brushing frequency and DMFT scores, which showed a significant difference between the two groups $(p<0.05)$ (Additional file 5).

\section{Discussion}

In the present study, saliva was particularly selected as the sampling medium to assess the microbial aspect of dental caries. Salivary SM and LBs enumeration may be considered a reflection of an individual's oral load of these bacteria [15-17]. It is expected that the use of saliva samples in this study provides a generalized picture of the microbial load of these species, and when measuring relative counts, the risk trend of caries in all dentitions can be emphasized. In addition, sampling from caries lesions for CA individuals was considered. Other studies also reported the detection of elevated numbers of LBs and $S M$ in carious samples by using qPCR [18].

In this study, the detection of $S M$ and LBs in the salivary and carious tissue samples was $100 \%$, which is consistent with the results of Kishi et al. [19], who revealed a
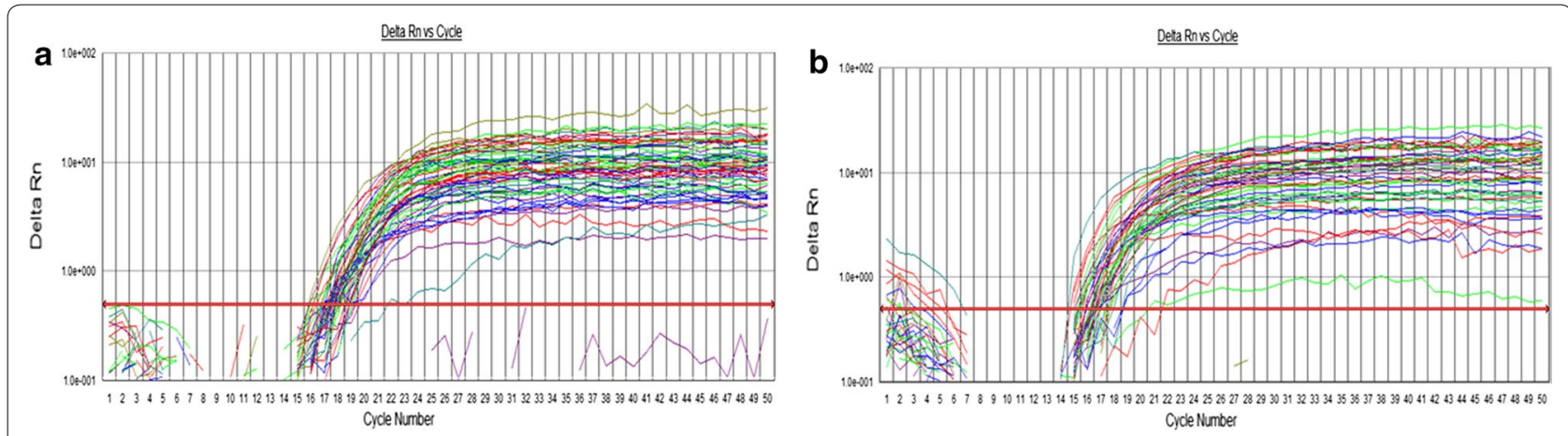

Fig. 1 Quantification graph of SM (a) and LB (b) from saliva and caries tissue samples using $16 S$ RNA specific primers to quantification of specific Bacteria in caries active and caries free. Successful amplification was achieved in all samples whilst the NTC showed negative amplification with no detectable Ct value 
Table 2 Comparison of the relative amounts of tested bacteria with DMFT index in the caries-active and caries-free groups by using Kruskal-Wallis and Mann-Whitney $U$ tests

\begin{tabular}{|c|c|c|c|c|c|c|c|}
\hline & $\begin{array}{l}\text { Caries-active } \\
\text { Median }\end{array}$ & Caries-free & $p$ & $\begin{array}{l}\text { CF saliva } \\
\text { Median }\end{array}$ & CA saliva & Caries tissue & $p$ \\
\hline$S M$ & $4.1 \times 10^{6}$ & $4.9 \times 10^{6}$ & $0.001^{* a}$ & 4.4 & $4.6 \times 10^{6}$ & $4.4 \times 10^{6}$ & $0.006^{* b}$ \\
\hline LBs & $3.3 \times 10^{6}$ & $3.5 \times 10^{6}$ & $0.000^{* a}$ & 3.3 & $3.2 \times 10^{6}$ & $3.3 \times 10^{6}$ & $0.001^{* b}$ \\
\hline DMFT & 8.0 & 0 & $0.000^{* a}$ & 0 & 9.0 & & $0.000^{* b}$ \\
\hline CF saliva & & & & - & $0.000^{* c}$ & $0.000^{* c}$ & \\
\hline CA saliva & & & & $0.016^{* d}$ & - & 1.000 & \\
\hline \multirow[t]{2}{*}{ Carious tissue } & & & & $0.004^{*}$ & 1.000 & - & \\
\hline & $S M$ & LB & DMFT & & & & \\
\hline Decayed & $0.001^{* f}$ & $0.000^{* f}$ & $0.000^{*} \mathrm{~g}$ & & & & \\
\hline Missing & 0.620 & 0.275 & $0.016^{*} 9$ & & & & \\
\hline Filled & 0.174 & 0.194 & $0.032^{*} g$ & & & & \\
\hline
\end{tabular}

${ }^{*} \mathrm{p}<0.05,{ }^{\mathrm{a}} \mathrm{SM}, \mathrm{LBs}$, and DMFT score in caries-active and caries-free subjects; ${ }^{\mathrm{b}} \mathrm{SM}, \mathrm{LBs}$, and DMFT score in the three types of samples (caries-free saliva, caries-active saliva, and carious tissue); ${ }^{c}$ difference between samples in relation to DMFT score; ${ }^{d}$ difference between samples in relation to SM and ${ }^{\mathrm{e}}$ to $\mathrm{LBs}^{\mathrm{f}}{ }^{\mathrm{f}}, \mathrm{g}$ decayed, missing, and filled in relation to $\mathrm{SM}, \mathrm{LBs}$, and DMFT score

frequent detection of $S M$ in saliva samples (100\%), which was significantly related to the DMFT score.

Our results also indicated that the detection of $S M$ and LBs was in the CA and CF saliva; however, the levels of both kinds of bacteria appeared to be higher in the CA subjects than in the CF subjects. Individuals with lower concentrations showed a significantly lower mean number of decayed surfaces than did the individuals with higher concentrations of $S M$ in their saliva [20]. The current study also showed an inverse correlation between the levels of $S M$ and LBs, but the difference was not statistically significant. These findings are in agreement with Chen Lin et al. [14], who found no significant association between $S M$ and LBs (Additional files 1, 2, 3, 4, 5).

Positive associations were noted between caries development and the level of $S M$ in saliva samples. These results agree with the studies conducted by other authors who reported a positive association between the concentration of $S M$ in saliva and dental caries [19, 21, 22]. A negative correlation between $S M$ and LBs in caries tissue samples was supported by the hypothesis that $S M$ and LBs are more competitive under certain acidic conditions [23]. A result of an in vitro study, which was supported by this study, showed that LBs were capable of preventing the growth of $S M$ [24].

LBs are prominent organisms in dental caries, and a relatively high proportion is found in cavity lesions, suggesting that their role in caries may lie in progression and advanced caries rather than in initiation of disease [25]. Simón-Soro et al. [26] took samples from carious enamel and carious dentin and revealed that the proportion of $S M$ was greater in dentin caries, whereas LB abundance was greater in deep dentin lesions. This result was in agreement with our findings, in which the level of LBs appeared to be higher in carious tissue than in saliva among the CA group. However, another study carried out on adults revealed a strong relationship between root caries and the level of salivary LBs [27].

The current study found that the bacterial counts and DMFT index were not influenced by daily oral habits with the exception for tooth brushing, for which there was a positive relationship with DMFT score. These findings agreed with a previous study [28].

It can be concluded that $S M$ and LBs could be detected quantitatively and sensitively by qPCR. Higher $S M$ and LB counts were observed in CA subjects, and the lowest counts were observed in the CF subjects. $S M$ and LB counts showed a positive correlation with DMFT scores in the group with dental caries, which likely reinforces their relationship with dental caries development.

\section{Limitations}

A cross-sectional study design was used in the present study to determine the correlations among $S M$, LBs, and caries rates. However, a single saliva sample records the microbial counts at one particular point of time, and it is well understood that dental caries develops over a considerable period of time, during which bacterial counts could fluctuate in response to the changing oral environment [22]. Moreover, the number of CF and CA samples studied was limited; further study with a larger sample should be performed to confirm these results. 


\section{Supplementary information}

Supplementary information accompanies this paper at https://doi. org/10.1186/s13104-020-04960-3.

Additional file 1: Figure S1. Distribution of the study sample.

Additional file 2: Table S1. Bacterial-specific primers for quantitative realtime polymerase chain reaction.

Additional file 3: Table S2. Mean (standard deviation [SD]) of Streptococcus mutans, lactobacilli, and DMFT score in caries-free and caries-active subjects.

Additional file 4: Figure S2 PCR successful amplification of positive control for SM and LB species with $256 \mathrm{bp}$ and $430 \mathrm{pb}$, respectively. Electrophoretic separation of a fragment of $415 \mathrm{bp}$ of gene gtfB and $22316 \mathrm{~S}$ rDNA in 2\% agarose gel amplified by means of PCR. Lane 1 corresponds to a standard molecular size of $1 \mathrm{~kb}$. Lanes 2 and 3 correspond to amplification, using the DNA of S. mutans UA159. Lanes 4 and 5 correspond to amplifications using DNA.

Additional file 5: Table S3. Median (25th, 75th percentiles) Streptococcus mutans, lactobacilli, and DMFT index in relation to different daily habits in caries-free and caries-active subjects

\section{Abbreviations}

SM: Streptococcus mutans; LBs: Lactobacilli; LB: Lactobacillus; qPCR: Quantitative polymerise chine reaction; CA: Caries-active; CF: Caries-free; DMFT: Decayed, missing and filled teeth.

\section{Acknowledgements}

The authors thank the management of the College of Dentistry, the PCR research centre of UST, the Hospital of the University of Science and Technology for their assistance and support, and Yemen Agrivet for their support.

\section{Authors' contributions}

SS contributed to the research concept, study design, sample collection, laboratory steps, DNA extraction, data collection, statistical analysis, writing the original draft and reviewing and editing the final manuscript. AM contributed to the research concept, study design, supervision, statistical analysis, writing the original draft and critical reviewing and editing of the final manuscript. Both authors read and approved the final manuscript.

\section{Funding}

Not applicable.

\section{Data availability}

The data used and/or analysed during the present study is included as supplementary file. Any additional data and material are available from the corresponding author on reasonable request.

\section{Ethics approval and consent participate}

Approval was obtained from the Institutional Review Board and ethics committee at the Faculty of Medicine and Health Sciences at UST (MECA No. 2017/01). Written informed consent was obtained from all individual participants included in the study.

\section{Consent for publication}

The manuscript does not contain any individual person's data in any form.

\section{Competing interests}

The authors declare no competing interests.

\section{Author details}

${ }^{1}$ Department of Restorative and Prosthodontics, College of Dentistry, University of Sciences and Technology, Sanaa, Yemen. ${ }^{2}$ Department of Conservative Dentistry, Faculty of Dentistry, Thamar University, Dhamar, Yemen. ${ }^{3}$ Department of Restorative Dental Science, College of Dentistry, University of Hail, Hail, Kingdom of Saudi Arabia.
Received: 25 January 2020 Accepted: 18 February 2020

Published online: 27 February 2020

\section{References}

1. Chokshi A, Mahesh P, Sharada P, Chokshi K, Anupriya S, Ashwini B. A correlative study of the levels of salivary Streptococcus mutans, lactobacilli and Actinomyces with dental caries experience in subjects with mixed and permanent dentition. J oral Maxillofac pathol. 2016;20(1):25.

2. Neves BG, Stipp RN, da Silva Bezerra D, de Figueiredo Guedes SF, Rodrigues LKA. Molecular detection of bacteria associated to caries activity in dentinal lesions. Clin Oral Invest. 2017;21(6):2053-61.

3. Zickert I, Emilson CG, Krasse B. Streptococcus mutans, lactobacilli and dental health in 13-14-year-old Swedish children. Community Dent Oral Epidemiol. 1982;10(2):77-81.

4. Thibodeau EA, O'Sullivan DM. Salivary mutans streptococci and caries development in the primary and mixed dentitions of children. Community Dent Oral Epidemiol. 1999;27(6):406-12.

5. Krasse B. Biological factors as indicators of future caries. Int Dent J. 1988;38(4):219-25.

6. Holbrook W, De Soet J, De Graaff J. Prediction of dental caries in preschool children. Caries Res. 1993;27(5):424-30.

7. Yoshida A, Suzuki N, Nakano Y, Kawada M, Oho T, Koga T. Development of a $5^{\prime}$ nuclease-based real-time PCR assay for quantitative detection of cariogenic dental pathogens Streptococcus mutans and Streptococcus sobrinus. J Clin Microbiol. 2003;41(9):4438-41.

8. Manmontri C. Real-time quantitative PCR for evaluation of mutans streptococci and dental caries. Alabama: University of Alabama at Birmingham, Graduate School; 2012.

9. Sulyanto R: The natural history of oral bacteria acquisition in the developing infant. The Ohio State University; 2013.

10. ElSalhy M: Relationship between Daily Habits, Oral Microbiota and Caries with Special Reference to Xylitol. Dissertation, University of Turku, http:// urn.fi/URN: ISBN:978-951-29-5823-8; 2015

11. Bezerra DS, Stipp RN, Neves BG, Guedes SF, Nascimento MM, Rodrigues LK. Insights into the virulence traits of Streptococcus mutans in dentine carious lesions of children with early childhood caries. Caries Res. 2016:50(3):279-87.

12. Rôças IN, Lima KC, Assunção IV, Gomes PN, Bracks IV, Siqueira JF Jr. Advanced caries microbiota in teeth with irreversible pulpitis. Caries Res. 2015;41(9):1450-5.

13. Kuribayashi M, Kitasako Y, Matin K, Sadr A, Shida K, Tagami J. Intraoral pH measurement of carious lesions with qPCR of cariogenic bacteria to differentiate caries activity. J Dent. 2012;40(3):222-8.

14. Chen L, Mao T, Du M, Yang Y, Xu Q, Fan M. Caries status and quantification of four bacteria in saliva of Chinese preschool children: a cross-sectional study. J Dent Sci. 2014;9(3):283-8.

15. Conrads G, de Soet JJ, Song L, Henne K, Sztajer H, Wagner-Döbler I, Zeng A-P. Comparing the cariogenic species Streptococcus sobrinus and S. mutans on whole genome level. J oral Microbiol. 2014;6(1):26189.

16. Karpiński TM, Szkaradkiewicz AK. Microbiology of dental caries. J Biol Earth. 2013;3(1):21-4

17. Tanzer JM, Livingston J, Thompson AM. The microbiology of primary dental caries in humans. J Dent Educ. 2001;65(10):1028-37.

18. Byun R, Nadkarni MA, Chhour K-L, Martin FE, Jacques NA, Hunter N. Quantitative analysis of diverse Lactobacillus species present in advanced dental caries. J Clin Microbiol. 2004;42(7):3128-36.

19. Kishi M, Abe A, Kishi K, Ohara-Nemoto Y, Kimura S, Yonemitsu M. Relationship of quantitative salivary levels of Streptococcus mutans and S. sobrinus in mothers to caries status and colonization of mutans streptococci in plaque in their 2.5-year-old children. Commun Dent Oral Epidemiol. 2009;37(3):241-9.

20. Alaluusua S. RENKONEN OV: Streptococcus mutans establishment and dental caries experience in children from 2 to 4 years old. Eur J Oral Sci. 1983;91(6):453-7.

21. Dasanayake A, Caufield P, Cutter G, Roseman J, Köhler B. Differences in the detection and enumeration of mutans streptococci due to differences in methods. Arch Oral Biol. 1995;40(4):345-51.

22. Lindquist $B$, Emilson C. Distribution and prevalence of mutans streptococci in the human dentition. J Den Res. 1990;69(5):1160-6. 
23. Takahashi N, Nyvad B. The role of bacteria in the caries process: ecological perspectives. J Dent Rese. 2011;90(3):294-303.

24. Simark-Mattsson C, Emilson CG, Håkansson EG, Jacobsson C, Roos K, Holm S. Lactobacillus-mediated interference of mutans streptococci in caries-free vs caries-active subjects. Eur J Oral Sci. 2007;115(4):308-14.

25. Holbrook W. Dental caries and cariogenic factors in pre-school urban Icelandic children. Caries Res. 1993:27(5):431-7.

26. Simon-Soro A, Belda-Ferre P, Cabrera-Rubio R, Alcaraz L, Mira A. A tissuedependent hypothesis of dental caries. Caries Res. 2013:47(6):591-600.

27. Beighton D, Hellyer P, Lynch E, Heath M. Salivary levels of mutans streptococci, lactobacilli, yeasts, and root caries prevalence in non-institutionalized elderly dental patients. Commun Dent Oral Epidemiol. 1991;19(5):302-7.

28. ElSalhy M, Honkala S, Söderling E, Varghese A, Honkala E. Relationship between daily habits, Streptococcus mutans, and caries among schoolboys. J Dent. 2013;41(11):1000-6.

\section{Publisher's Note}

Springer Nature remains neutral with regard to jurisdictional claims in published maps and institutional affiliations.
Ready to submit your research? Choose BMC and benefit from:

- fast, convenient online submission

- thorough peer review by experienced researchers in your field

- rapid publication on acceptance

- support for research data, including large and complex data types

- gold Open Access which fosters wider collaboration and increased citations

- maximum visibility for your research: over $100 \mathrm{M}$ website views per year

At BMC, research is always in progress.

Learn more biomedcentral.com/submissions 